There are few studies on how states have grappled with the issue of expanding educational opportunity. Scholarship has focused largely on the general development of the American college and the research university or on individual institutions, ignoring the intricacies and influence of regional and state politics. ${ }^{1}$ However, the regional context of policymaking, as well as the interplay between the academy and state and local governments, and ultimately with the taxpayer, is historically one of the most important influences on the organization, funding, and mission of American higher education.

This book is the first attempt at a comprehensive history of public higher education in California. ${ }^{2}$ Hence, the following narrative does not simply chronicle the founding and building of colleges and universities. Bricks and mortar and the difficulties of hiring faculty and creating management structures are, in fact, a relatively small part of this effort. The story of California's pioneering public higher education system is inseparable from the political, social, and economic landscape from which it grew. I have attempted to provide the reader with a sense of the contextual influences and the actions of individuals that drove policymaking. The exigencies of segregated schools, capitalist conspiracies (both real and imagined), reform movements, depressions, world wars, the perceived threat of Communist subversives, tax revolts, and more generally philosophical debates over the role of higher education in socioeconomic mobility and American economic development all play an important part in this narrative.

In writing this book, I readily admit to the difficulty of trying to do justice to such an expansive subject. The saliency of higher education in the modern world has led to a proliferation of books, essays, and archival collections. But the lack of previous attempts to analyze the movement toward mass higher education at the core level of policymaking has made this effort a perplexing assignment.

I received guidance and encouragement along the way from a number of 
people, foremost Elliot Brownlee at the University of California-Santa Barbara, who has been both a mentor and friend. Other important influences include Clark Kerr, Dean McHenry, Vernon Cheadle, Kevin Starr, Hugh Graham, Nancy Diamond, Barry Munitz, Suzanne Ness, A. Alan Post, Hubert Semens, Dorothy Knoell, Martin Trow, Sheldon Rothblatt, Burton Clark, Patrick Callan, Lyman Glenny, Howard Bowen, Duncan Mellichamp, Calvin Moore, Richard Jensen, and my colleagues at the Center for Studies in Higher Education (University of California-Berkeley), in particular Arnie Leiman, and also Marian Gade, Diane Harley, Carroll Brentano, and Anne Maclachlan. More distantly, yet still influential, have been people such as David Riesman, Roger Geiger, David Gardner, Richard Atkinson, Verne Stadtman, Eugene Lee, Neil Smelser, Jack Smart, Clive Condren, Jurgen Herbst, and Daniel Aldrich. Each has, through conversation or writing, influenced my effort at one time or another.

Indeed, perhaps the most gratifying aspect of the entire experience has been the opportunity to talk with and listen to those who have shaped American higher education, understood its complexities and challenges over time, and articulated its intellectual and social raison d'être. Clark Kerr in particular-one of the intellectual giants of American higher education in the twentieth century - has often offered not only his unique insights into the trials and tribulations of California's higher education system but also a kind ear and a gentle manner.

I am also deeply grateful for the financial support provided by the Spencer Foundation in the form of a two-year postdoctoral fellowship, which partially relieved me of my duties as a university administrator at a critical juncture in my research. In association with the National Academy of Education, the Spencer Fellowship offered me new venues and new people to meet. In retrospect, this experience was essential for completing this book in addition to a series of publications. I also must credit my fortunate circumstance of working for the university-wide Academic Senate as an administrator and policy analyst. The Academic Senate is a community of scholars who, on the whole, saw worth in my research and writing. My arrival at the Center for Studies in Higher Education provided a final and current environment of support and encouragement.

As the reader will undoubtedly notice, archival materials provide the most important sources of information for this book. The librarians and archivists who have helped me are too numerous to mention. However, I must note the assistance and guidance of William Roberts, the UC archivist, along with the staff at Bancroft Library (UC-Berkeley), the California State Archives, 
the California State Library, and Karen Jean Hunt at the California State University Archives located at CSU-Dominguez Hills.

I extend my thanks as well to Norris Pope at Stanford University Press, and I appreciate the hard work and patience of Kate Washington, Stacey Lynn, and Lisl Hampton in helping to produce the final manuscript.

Last but not least, I must thank my family and friends. Perhaps my focus on higher education policy has genetic routes? I prefer to think it has more to do with my general interest in using history to understand contemporary policies and politics. The reader may sense that it is the latter since my grandfather, whom I never met, was an education advisor to California Governor Earl Warren and headed the state teachers colleges in the immediate postWorld War II era. He was also a protégé of G. Stanley Hall, the psychologist and president of Clark University. I am grateful to my father and mother, Malcolm and Enid Douglass, for constant support and conversations about the world of Hall and John Dewey, my grandfather's encounters in the state capitol, and the political world of higher education. My sister Susan, an oral historian at University of California-Los Angeles, has also helped to broaden my knowledge of California, as has my brother who teaches at San Jose State University. Dario Caloss, Larry Martinez, and Tye Simpson have always been ready to share their thoughts on the pitfalls and triumphs of the sometimes lumbering, sometimes innovative, and always largest system of public higher education in the nation. To end this inadequate list of influences and sources of support, I want to thank my wife, Jill, and our two great kids, Claire and Aubrey, for their patience, understanding, and help.

John Aubrey Douglass

Center for Studies in Higher Education

UC Berkeley, November 1999 



\section{THE CALIFORNIA IDEA}

and

AMERICAN HIGHER EDUCATION

1850 to the 1960 Master Plan 
